cemoti $\begin{aligned} & \text { Cahiers d'études sur la Méditerranée } \\ & \text { orientale et le monde turco-iranien }\end{aligned}$

19 | 1995

Laïcité(s) en France et en Turquie

\title{
Eurasian Energy Prospects and Politics: Need For a Fresh Perspective
}

Mehmet OĞÜTÇÜ

\section{(2) OpenEdition \\ 12 Journals}

\section{Electronic version}

URL: http://journals.openedition.org/cemoti/1705

DOI: $10.4000 /$ cemoti. 1705

ISSN: $1777-5396$

Publisher

AFEMOTI

Printed version

Date of publication: 1 January 1995

ISSN: 0764-9878

\section{Electronic reference}

Mehmet OĞÜTÇÜ, « Eurasian Energy Prospects and Politics: Need For a Fresh Perspective », Cahiers d'études sur la Méditerranée orientale et le monde turco-iranien [Online], 19 | 1995, Online since 14 May 2006, connection on 08 September 2020. URL : http://journals.openedition.org/cemoti/1705 ; DOI : https://doi.org/10.4000/cemoti.1705

This text was automatically generated on 8 September 2020

Tous droits réservés 


\title{
Eurasian Energy Prospects and Politics: Need For a Fresh Perspective
}

\author{
Mehmet OĞÜTÇÜ
}

1 The collapse of communism in Europe and the former Soviet Union has transformed world geopolitics and energy map. Now that nearly five years have elapsed since the demise of the Soviet Union, the previously little known vast territory of Eurasia is forcefully entering the global scene on many fronts in which its energy resources and associated problems that crop up figure prominently. Access to the region was heavily restricted under the communists and only recently has Eurasian scholarship become fashionable in the West. This region, the boundaries of which is difficult to draw precisely, encompasses more than twice the territory of the Middle East and compels the world to rethink the traditional views of its security, political and economic significance, its power structures and the consequences that current changes portend for the world energy prospects. The long-term world energy picture is difficult to draw if one ignores this large energy-rich territory and the strategic challenges that it poses to the Western world.

2 Energy has today become the driving force of the global economy and, in the next century, it will no doubt remain the pillar of economic and social development. The demand for energy is set to increase apace with economic growth in the medium term and population growth in the longer term. The substantial oil price increases of 1973/74 and 1979/80 had a major impact on fuel substitution, energy conservation and energy policy and compelled the Western countries to expand their strategic reserves and invest billions of dollars in opening up new reserves, developing alternative energies and improving end-use efficiency and conservation. However, with the lack of further growth in oil/gas prices, interest has gradually waned and now future energy markets are facing uncertainties arising from energy policies in general and environmental requirements in particular. These uncertainties call for a rethinking of 
global/regional energy policies and the development, to the extent possible of a unified approach.

3 Hans Morgenthau used to say that in every generation we engage in what he called geo-cartography. That is, trying to put together a new map which, like all maps, is a simplification of reality, but helps us understand where we are. We had a map that served well for 45 years and a new political map has been now shaped in most continents. The world energy map, too, has been redrawn as a result of the dramatic changes that have taken over the past five years. The new energy map will, in its final shape, affect the forces of economic integration, collective concepts, geopolitics and security arrangements. Alter all, let's not forget that al] the conflicts in recent history were, in one way or another, related to or even stemmed from energy crisis.

During the Cold War years, Free World access to oil supplies, especially those of the Middle East, was one of the premier foreign policy interests of the Western world. All of the recent Middle Eastern confrontations, from the initial Arab-Israeli conflict of 1947 and the first Iranian crisis of 1951-52 to the Suez crisis of 1956 and the Arab-Israeli wars of 1967 and 1973, have elicited concern about the strategic consequences of losing control over Middle Eastern oil supplies. With proven reserves of 891 billion barrels, an estimated field growth potential of 175 billion barrels, and perhaps 547 billion barrels remaining to be discovered, it is believed that intensive development could sustain current world oil production levels well into the next century. However, world oil reserves and resources are very unevenly distributed. Despite new discoveries in other regions, the countries with the greatest potential for long-term sustained production and significant increases in production are located in the Persian Gulf. And the end of the Cold War bas done little to diminish the Western interest in the security of the oil supplies from the Middle East. To the contrary, the dependence on Middle Eastern oil is projected to grow stronger in the next decade. The oil reserves in the region make therefore it inevitable that any practical change around the Persian Gulf will continue to attract world attention. This has indeed been a factor in the region's internal politics since the break-up of the Ottoman Empire alter the First World War. The Western oil stakes are simply too high so that the Middle Eastern countries will not be allowed, in the words of Krapels" ${ }^{1}$ even "to sort out their own rivalries without substantial Western attention and intervention." It is, on the other hand, ironic that the Western community of nations, while not hesitating to wage a costly war in order to keep the Kuwaiti oil fields from changing hands, virtually ignores the possibility of what may happen in the event of the rich oil and gas fields of Western Siberia (Russia), Kazakhstan, Turkmenistan and Azerbaijan falling into unfriendly, anti-Western hands ${ }^{2}$.

This region has been the world's leading oil producer since 1976. The, sheer extent of the territory and the apparent site of the potentially recoverable petroleum and gas resource base make the Eurasian space one of the tomorrow's oil \& gas exporting superpowers. The outcome of the current developments in Eurasia, sounding as though the 20th century version of the Great Game is being replayed among new major powers, will therefore determine the future shape of a vast geography covering the Middle East, the Balkans, the Trans-Caucasus and Central Asia and, by this token, the very security of the world's major supply areas of oil and natural gas. It is for this reason that the EU, alongside other major Western powers, should speedily undertake a comprehensive review of its presently ambiguous Eurasian strategy and think over its longer-term interests in the region. There is a pressing need for the formulation of a new EU 
strategy encompassing all aspects of its relationship with the Eurasian countries and, in this context, we believe, energy co-operation offers an excellent opportunity. The recently concluded Energy Charter Treaty may serve as an institutional and legal framework within which further co-operation can be fostered and existing problems can be arbitrated.

6 For the sake of this article, whenever we mention energy commodities, they should be taken as referring mainly to oil and gas -- the two precious assets abundantly found in Eurasia and most sought after in global energy markets. We shall intentionally omit here other sources of energy in Eurasia, which are by no means negligible by world standards. It is beyond doubt that the Eurasian region would be among the most strategic in the world for energy resources as oil and gas are set to be the engines for the ongoing economic and political transformation in this vast landmass and given that the Western dependence on imported oil and gas is likely to increase over the next decades. The former Soviet Union had unique wealth of natural energy resources as one of the few countries capable of satisfying all its energy requirements on a selfsufficient basis. Now that the disintegration had taken place, most of the oil and gas reserves of the former Soviet Union are located in Russia; recent estimates of $162 \mathrm{bn}$ barrels of proven, probable and possible oil reserves in the former Soviet geography assign 137 bn to Russia, 15 bn to Kazakhstan, 4 bn to Azerbaijan, 3.2 bn to Turkmenistan and $2.8 \mathrm{bn}$ to other countries of the $\mathrm{CIS}^{3}$.

7 The Caspian Sea, at the center of some of the world's least known states, is growing into a major oil and natural gas producing region. According to Rob Sobhani of Georgetown University ${ }^{4}$, with as much as 50 bn barrels of reserves, the Caspian Sea area, second only to the Persian Gulf in terms of oil reserves, can become a stable source of oil for the West over the next forty years. In fart, the Caspian Sea projects are estimated to produce more than two million barrels per day - equivalent to what the US imports from OPEC's Arab members and a little less than the total Chinese production. Most regions in the Caspian either have never been identified or never tapped. Expected economic growth, boosted by oil and gas export earnings, could spill over and fuel expansion in two of the former Soviet Union's mort backward regions : Central Asia and the Caucasus. The Caspian Sea, actually the world's largest lake, covers 600.000 square $\mathrm{km}$, but the geological region extends much further. The Caspian Depression reaches across the northern Caspian Sea into Western Kazakhstan and includes the long producing Russian oil and natural gas fields of Astrakhan, Orenburg and Volvograd. Another formation crosses the Sea's said-section, called the Northern Caucasian Mangeshlak plate, encompassing the fields of Azerbaijan and Turkmenistan and stretching to the Ai-al Sea. There are numerous untested structures out in the Caspian Sea; also, deeper horizons offer good prospects ${ }^{5}$. Held back during the Soviet times by lack of capital and technology, the fields of the newly independent Kazakhstan, Azerbaijan and Turkmenistan hold billions of barrels of oil and rich reserves of natural gas.

8 Currently, the Newly Independent States (NIS) area ranks seventh in the world in proven reserves - Saudi Arabia, Iraq, Kuwait, Iran, Abu Dhabi, Venezuela and the former USSR, followed by Mexico and the US. It is estimated that the region contains more than one third of the world's gas resources. Now that the countries around the Caspian Sea are independent, they can better control their destinies : They are small enough for the Western prospector to find his/her place without having to deal with 
the overpowering bureaucracy of Russia. They are also receptive to Western participation in their own local industries. As Western companies move toward the arrangement that will permit the joint development of these reserves, one question mark looms ever larger - how to get the Caspian oil to the world market? The chief problem is shipping the Eurasian oil and gas exports to the international market over huge distances from a region landlocked by often unfriendly, rival or unstable suites. The fate of both resource development and the entire industrial base depends on the development of a secure and efficiently-run network of pipelines that can transport oil and gas to the deep water ports for sale in the world currencies. Without such pipelines in place, says the Chevron President ${ }^{6} 7$, "we will only have a pipedream. in that region ".

We believe that the end of the Cold War bas created new opportunities for regional economic co-operation and integration between Europe and Eurasia, where energy is poised to play a pivotal role. In Tact, the former Soviet Union used to cover about 25\% of West European energy imports -in 1988 the Soviet energy deliveries to the OECD area amounted to about $93 \mathrm{mmt}$ (million metric tones) of crude oil and products, $38 \mathrm{bcm}$ (billion cubic meters) of natural gas, and to $21 \mathrm{mmt}$ of hard Goal - a total of about 140 $\mathrm{mmt}^{7}$. The European Union has since thon become even more vulnerable in its energy supplies, especially oil and gas supplies, with nearly half of its energy requirements being now met by imports and this degree of dependence is likely to increase in the longer term according to the IEA's 1994 World Energy Outlook. Western Europe has about $4 \%$ of world total gas resources, while accounting for about $10 \%$ of total consumption in 1992. Despite a substantial increase in indigenous production, attributable largely to Norway and the United Kingdom, Western Europe will increasingly depend on non-OECD gas imports. There is therefore a danger that the Union might become excessively reliant on a small number of countries, or even on a single production region, where political stability is at risk. The natural gas demand of the EU countries is estimated to reach $300 \mathrm{bcm}$ by the year 2010, compared to the present $220 \mathrm{bcm}$. This growth of about $35 \%$ will mean that the share of natural gas in Europe's primary energy consumption will rise from $18 \%$ to $23 \%$ in the came period. Local production of gas, now some $135 \mathrm{bcm}$, is set not to rise significantly over the next 20 years, increasing to $140 \mathrm{bcm}$ by 2000 , but then falling off to $120 \mathrm{bcm}$ by 2010 .

The resulting supply and demand picture for the whole region is therefore likely to entail net import requirements at about $140 \mathrm{bcm}$ by 2000 and $180 \mathrm{bcm}$ by $2010^{8}$. The crucial question is : Where would the new supplies come from? The answer is simple : inevitably mainly from outside the Western Europe. Currently, just over $20 \%$ of continental Europe's gas is supplied by the NIS, principally Russia and Turkmenistan (Algeria is also an important gas supplier; but its stability is shaky and reserve/ production ratio is put at 54 years. Norway's expected accession to the EU was likely to further improve the EU's gas supply situation; but a December 1994 Norwegian referendum postponed accession bid beyond the next century). Virtually all this gas is piped across former Czechoslovakia and the Ukraine. However, recent disputes over payment and transit tariffs led to temporary reductions in exports to both Western and Eastern Europe. With Germany and Italy reliant on NIS gas for more than a third of their supply and Turkey more than $90 \%$, these disruptions clearly cause major concern in Western Europe. Although the Middle East will continue to supply most of the growing demand for oil and some natural gas, alternative supply routes are considered necessary particularly from the viewpoint of energy supply security. 
11 Against this background, where might Turkey's role be found in the complex energy picture of the Eurasian world? Turkey, standing as it does at the geo-center of the Eurasian world and at the juncture of strategic energy transportation routes, is destined to play a critically important rote in any energy trade between the Eurasian (and some Middle Eastern) suppliers and the European consumers - a rote, which require wisdom, creativeness and strategic thinking on the part of Turkish leadership given the magnitude of the existing political sensitivities and economic problems in the region. The pressure on Turkey (a major oil and gas importer itself) from the oil and gas exporting states of the Caspian region is expected to grow stronger as these countries in need of hard currency would want to pump as much oil and gas as possible to the world markets. And the ability of Turkish energy diplomacy in formulating a viable response to this historic challenge is no doubt to affect profoundly the future course of Turkey's relations, not only with the West, but also with the Eurasian countries, beyond the 21st century.

Current Energy Situation in the European Union

12 We shall narrow our focus here mainly to the EU as it is considered to be the biggest single market in the West for Eurasian energy production. The problem of security supply at the EU level is a priority matter given that the Union is a major energy consumer in the international energy arena. (Incidentally, because of a lack of external energy policy, the EU is not yet a major world energy player). Security of supply is and will, for long time to come, remain a central objective of any European energy strategy. The European Commission's Energy Commissioner identified four policy pillars ${ }^{9}$ in this field with the future security of energy supply topping the lest. Others include the recognition of the global nature of the energy markets and the international interdependence between all the major producers and consumers ${ }^{10}$-- a strategy, based on market principles (albeit, a special and a strategy commodity, energy is still one which should be traded according to market principles) and environmental protection. To this must be added the objective of improving industrial competitiveness. Steps have already been taken in recent years towards achieving these goals by means of specific measures in several areas such as efficient use of energy, development of the EU's resources, diversification of external supplies, technological development and dissemination of innovation. These measures now need to be reviewed and supplemented in the light of recent developments, namely the completion of the Internal Energy Market, the opening-up, economically and politically, of Eastern and Central European Countries and the NIS and the Union strategy to combat C02 emissions.

Energy strategy undoubtedly bas an increasingly global dimension requiring global solutions. It cannot be confined to the national or EU dimension, since the EU countries depend on external sources for nearly half their energy supplies. In this context, the efforts to co-operate with the former Soviet republics, the new Mediterranean policy and the resumption of negotiations with the Gulf Co-operation Council to establish a free-trade area need no further elaboration. It is generally acknowledged by energy experts that the need for an energy chapter in the Treaty on Political Union is more pressing than ever. The fact remains, however, that member states have still distinct energy markets with few interconnections and engage in hardly any trade at all, for instance, in electricity and natural gas. The Commission regards the creation of a free market in power and gas as one of the Most important elements in creating a single 
market for goods and services. Many energy companies have however stubbornly resisted attempts to open up the market. The factors determining the security of supply and availability of energy differ markedly. The price differentials for the various energy sources are often high for both private and industrial consumers (with competition obviously being distorted as a result). There are also more and more cases of specific energy actions or proposals dependent on the pursuit of other policy objectives. Examples of this include environmental policy (the fight against pollution and the greenhouse effect), support for crisis-ridden sectors (such as coal or farming) and tax regulations ${ }^{11}$. Efforts are being made by the Commission to foster intra-EU gas and electricity trade.

14 The complex problems surrounding the security of world energy supplies increase the need for the EU to present a strong united front, not only vis-a-vis the traditional oil and gas supplying areas, but also vis-a-vis the countries of Eurasia, whose share of the EU market is likely to increase in the near future, particularly alter the conclusion of the Energy Charter Treaty negotiations.

It bas become obvious that the current and future energy shortfall in the EU cannot be made up unless some more expansive reserves are mobilized in the traditional areas of supply, namely Russia. Norway and Algeria. Even so, these will be some requirement for new sources, but the financial resources needed to bring in such distant gas and oil to consumer areas are gigantic in comparison with the present financial capacities of the various partners. This shortcoming could be one of the major limitations on the EU economies unless coordinated solutions are sought and found for mobilizing capital and creating more flexible credit terms. To encourage the participation of financial institutions, multilateral and bilateral alike, and oil \& gas companies, which will mobilize all their resources to respond to the new demand, the consumer countries also need to contribute by being prepared to accept prices that will provide a reasonable return, taking into account the expected higher costs. It seems that the limitations faced today, notably financial, are likely to persist because the number of energy rich countries seeking foreign investors is on the increase. It may therefore be necessary to step boldly beyond the traditional types of co-operation implemented to date and tackle interactive schemes involving greater solidarity between partners. Such cooperation, based on a fairer sharing out of risks and earnings, would provide continuity of interest throughout oil and gas industries, from production site to consumer areas, and would help to ensure a better guarantee of secure markets for producers and secure supplies for consumers. The European Commission White paper and the Brussels European Council (December 1993), the work of the Christophersen Group in the first half of 1994 and the decisions of the Corfu European Council (June 1994) have successfully enabled the revival of projects concerning energy network. According to the White Paper, investment in Trans-European Energy Networks of ECU 30 billion is needed by the year 2000 .

It appears that natural gas supplies to the EU area are more or less guaranteed for the coming decade but alter, the turn of the century, increasing use will have to be made of distant reserves, including those in the former USSR. Moreover, the consumption of oil and gas in the NIS, too, already large, will continue to increase. Therefore, in the longer-term, Europe will have a vested interest in seeing the full exploitation of the large NIS reserves. The transport of gas over long distances will be profitable only if it is effected in large volumes and at a continuous rate. The cost of transportation from 
the Siberian fields to Western Europe (approx. $5.000 \mathrm{~km}$ ) is difficult to estimate precisely, but a rough estimate would be in the region of 20 cent/metre3. This is about the same as the price currently being paid by Western Europe.

We now turn to sketching out EU plans on how to respond to its future energy challenge. There are proposals for a new EU energy policy up to the year $2020^{12}$, which, if favorably received by the member states, could lead to the inclusion of energy policy measures within the Treaty on European Union when it will be revised in 1996. Energy policy was deliberately omitted from the Maastricht Treaty with member states (jealous of their national control) deciding that it was an area best loft to individual countries.

Towards A European Energy Charter

The Union is actively developing ideas for energy co-operation on a workable basis with Central \& Eastern Europe and the NIS, conscious of the growing problems in those areas which could put pressure in future on the world energy markets and particularly on the former Soviet gas supplies. And, on this score, the European Energy Charter Treaty (though it is no longer a "European" affair in its geographic coverage) deserves a special mention. It was first proposed in 1990 by the Dutch Government and is known as the Lubbers Plan with the aim of ensuring that the energy resources indigenous to the West, which will not last forever, be supplemented by those of Eastern Europe and the NIS. The fundamental purpose of the Charter is defined as opening up the energy resources of the former Soviet Union and Eastern Europe, encouraging investment and free trade, and ensuring reciprocal access to markets, as well as supporting transition towards democracy and market economy. The Treaty negotiated under the European Energy Charter is destined to become a cornerstone of the future Western energy policy. Just as the creation of the European Coal and Steel Community alter the Second World War become the symbol and the instrument of the ideal of no more war (particularly between France and Germany), the creation now of an energy union for the whole of Europe (but also for Such important non-European partners as the US, Japan, Canada and Australia) is likely to make an important contribution towards preventing new walls from dividing the old continent in the future. A union of this kind could also serve another general political aim - that of preventing Europe from becoming too heavily dependent on other parts of the world for its energy. More importantly, the Energy Treaty may also serve as a useful framework within which the controversial pipeline projects could be brought to a satisfactory conclusion. Going beyond the initial objectives, Eurogas, the European gas lobby group, called recently for the Energy Charter Treaty to be extended to the Magreb countries in view of the fart that the EU has become dependent on the Mediterranean for $24 \%$ of its total net energy imports ( $32 \%$ of its gas and $27 \%$ of its oil imports) ${ }^{13}$.

After a series of meticulous negotiations, the Charter was signed at the Hague on 17 December 1991 by 48 countries including all the members of the European Union, as well as the European Commission itself, all the other countries of Western Europe, nearly all the countries of Eastern Europe and all, except Turkmenistan, of the former USSR, three countries in the Mediterranean and four major non-European countries of the OECD, namely the US, Japan, Canada and Australia. Since the signing of the Charter, the participating countries negotiated the Charter's Basic Agreement (now "Charter Treaty") with a view to providing the legal basis for energy industries' operations and investment in all signatory countries. The energy sector was chosen for such an 
ambitious project because this sector offered the best prospects fur speedy and tangible economic returns for both sides. The Conference on Security and Co-operation in Europe (CSCE), 19-21 November 1990 in Paris, also voiced its support for the Lubbers plan. The Treaty addresses the issues which are crucial for East-West cooperation in energy i.e. investment protection, non-discrimination, market-orientated pricing, transit, minimizing environmental problems and open trading conditions. There are, however, still some fundamental technical difficulties to be resolved. Also, the nature of the negotiations in progress dues not make things any easier and, above all, the large number of participants slows things clown. The involvement of the non-European OFCD countries all too often transforms the discussions into a negotiation solely between the Western countries ${ }^{14}$. Last but not least, the economic and political instability of the former Soviet Union makes certain negotiators exceedingly cautious.

The negotiators finally agreed in December 1993 to a two-tier approach which was tabled by the EU, leaving aside the must ambitious and difficult part, namely the preinvestment protection, of the exercise until a later date. The EU scaled clown its initial ambitions because the main beneficiaries of the Treaty, the former Soviet republics, were not in a position to open up its market completely to the exploration of, and drilling for, oil and natural gas. The new compromise envisages that the provisions on pre-investment protection will not be included in the phase I Treaty ${ }^{15}$. Signatories will negotiate during a three-year period (beginning January 1995) the conditions under which the principle of national treatment to the pre-investment phase will apply and which exceptions to the principle are to be allowed. As a result of these negotiations, the number of exceptions included in their legislation and considered to be necessary at the time, if any, should be reduced to a minimum ${ }^{16}$. Russia decided to sign the Treaty alter last-minute consultations about trade in nuclear materials and repatriation of investments from Russia. The US raised a number of objections to the Treaty, which centered on how far the US federal government can go in committing individual States to treaties which it bas signed. The US wanted the Treaty text to specify chat the federal government would 'recommend' the Treaty to individual States but not 'oblige' them to apply it. However, it became clear during the Treaty negotiations that all the other participating countries with federal structures - notably Russia, Canada, Australia and Switzerland - would demand the same privilege. According to Energy Charter Conference Chairman Charles Rutten, there would then be no guarantees that the Treaty would be applied, leaving foreign investors with no certainty whatsoever ${ }^{17}$. Other US objections included lack of clarity about freedom of transfer of funds; definition of a "broad, overriding principle of state sovereignty" which may undercut the principle of investor protections; fallure to address tax obligations, particularly at the sub-federal level; and, lastly, denial to the US companies of benefits from economic integration agreements enacted between the EU and other Eastern signatories ${ }^{18}$. The Treaty, signed by forty-six nations in Lisbon on 18 December 1994 and expected to be ratified by the end of 1995, will likely bring about the following spin-off advantages for the West :

21 -- It would first help reduce Western dependence on OPEC for its oil supplies. Although there is some risk attached to reliance on NIS energy (in the event of high West-NIS tension or of internal disorder or collapse, supplies would be cut off), this danger should not be overstated; the NIS have up to now been a reliable supplier of energy to 
the West, and are likely to continue to be so if only because they need the hard currency for an al]-out economic reconstruction.

-- Second, the introduction of Western energy technology in the NIS would limit various environmentally-damaging discharges into the atmosphere (such as leaks of methane and oil from pipelines) and into soil, rivers and lakes. All the evidences demonstrate that real progress towards efficiencies in the NIS and Eastern Europe could quite significantly reduce world greenhouse gas emissions in the medium term.

23 -- Third, it will give the West better access to NIS energy resources. Access to energy markets according to GATT rules, even for Charter countries which are not yet GATT members will be ensured. This would work in three ways. More energy would be produced thanks to the introduction of Western technology, Energy efficiency measures would lead to a reduction in domestic energy demand, releasing more for export. In the long term the West could come to depend critically on the NIS's enormous supplies.

24 -- Fourth, it would lock the NIS and other East European countries more closely than hitherto into the Western financial and trading system. Closer co-operation would open up the NIS and East European energy sectors to Western companies.

25 -- Finally, freedom of transit for energy products through other Charter countries will be guaranteed and international arbitration in the case of disputes between governments and private companies will be possible.

26 It goes without saying Chat the NIS countries need to be reassured from the outset Chat they would equally benefit from such co-operation and that they would not lose control over the exploitation of their energy reserves. The following benefits might be identified from the NIS point of view:

27 -- Greater efficiency of production and consumption would release oil and gas supplies for export to the West, boosting the NIS's hard currency revenues; more hard currency would in turn enable greater investment in other sectors of the economy.

28 -- Greater efficiency and use of high technology would extend the longevity of reserves currently being exploited.

29 -- East European and NIS reformers would see an attraction in greater NIS-West economic interdependence. The energy sector will play a crucial role in the economic restructuring of three countries and the Energy Charter Treaty will provide the framework for energy co-operation.

30 -- Better management of NIS energy reserves and consumption would help respond to growing NIS awareness of its environmental problems.

31 -- Closer integration of the NIS energy sector with that of the West seems very likely also to contribute to a restructuring of the NIS economies. The expansion of hard currency outlets for NIS energy production, combined with more active involvement of Western companies and technology in exploration and exploitation, should increase the pressure for a more sensible price structure, greater independence for operators and better incentives for productivity and efficiency. And a restructuring of the energy sector, which of course plays a rote in most NIS economies, is bound to increase the pressure for a more general economic restructuring along the same lines.

32 -- Also, politically, the best security guarantee for their independence and sovereignty will be the presence of the Western business. The Kazakh President, Mr. Nazarbayev, 
during his official visit to London, made this point quite clear when he said : " I do not think that in today's world weapons can do anything to protect a country. Our main security guarantee (against Russia) will be a powerful Western business presence in Kazakhstan. "19.

Energy Outlook in the Eurasian Region

Production of all the key energy commodities - oil, coal, electricity and gas - has declined in the former Soviet Union since the 1991 collapse and the accompanying political \& economic turmoil. Since 1988, when $626 \mathrm{mmt}$ of oil produced, three bas been a downward trend in oil production ${ }^{20}$. In the IEA projections total NIS oil production declines further before stabilizing in the mid to late 1990s at a level more than $40 \%$ below its 1988 peak. It has been estimated that the NIS contains just under $40 \%$ of the world's known gas reserves. In 1991, gas represented over $40 \%$ of the total energy consumption in the NIS and accounted for approximately one third of total world gas consumption. To date, gas demand bas not registered the rapid drop that bas been experienced by other fuels, primarily because gas supply bas not had the same difficulties as oil. Old style subsidies to economy in general and to energy industry in particular were reduced or eliminated in all the republics. The 1992 oil production fell by $13 \%$ and gas production by $2.8 \%$ That year energy consumption in the NIS dropped an estimated $6.8 \%$. Against the drop in economic activity of 19 percent and industrial production of $23 \%$ the implicit waste of energy has not been much better than a year earlier when energy consumption dropped 2 percent against an economic decline of $10 \%{ }^{21}$.

Russian crude oil output totalled 314 mort in 1994 (6.3 mn barrels a day), down 11\% from $354.6 \mathrm{mmt}$ produced in $1993(7.1 \mathrm{mn} \mathrm{b} / \mathrm{d})$, according to estimates from the Russian Ministry of Fuel and Energy. For 1995, the Ministry bas forecast a 6\% output decline to $295 \mathrm{mmt}$, the lowest level since the $1970 \mathrm{~s}^{22}$. Even as production has dropped steadily, exports have grown. In the first 11 months of 1994, shipments outside the former Soviet territory totalled $87.8 \mathrm{mmt}(1.0 \mathrm{mn} \mathrm{b} / \mathrm{d})$, up $15 \%$ from the same period of 1993. Natural gas production is estimated to total $605.6 \mathrm{bcm}$ in 1994 (1.66 hem a day), clown $2 \%$ from 1993.

The combined proven reserves of the non-Russian former Soviet republics around the Caspian Sea (Kazakhstan, Azerbaijan and Turkmenistan) are estimated at $850 \mathrm{mmt}$ of oil and 8,700 bcm of gas. Geologists expect more fields to be discovered and think that they will have to revise reserves estimates upwards as the results from ongoing or planned exploration programs start coming in. Of the former Soviet republics, only two others besides Russia - namely, Kazakhstan and Turkmenistan -produce enough crude oil to supply their own refineries and only three (Kazakhstan, Turkmenistan and Azerbaijan) produce more crude oil than their internal consumption of refined products. But even Kazakhstan, the second largest oil producer among the republics, relied heavily upon Russia for its own oil supply. Most of the crude run through its refineries was brought in from Russia (Western Siberia), while most of its crude production was shipped out of the republic to be refined in Russia, Azerbaijan and Uzbekistan. Furthermore, its own refinery output is not large enough to supply the republic's own requirements for refined products, necessitating large imports of refined products from the surrounding republics, mainly Russia.

After Western Siberia, Central Asia is the second largest natural gas producing region in the former Soviet Union, accounting for $17 \%$ of total NIS output. Turkmenistan has 
25 producing fields, with must of the country's current gas output located in three regions : the Kopet Dag though along the border with Iran; onshore and offshore along the Caspian Sea; and along the Amu Darya River. Having an estimated 2.9 trillion cubic meters of proven gas reserves, Turkmenistan produced $60 \mathrm{bcm}$ of -as and exported 8.5 bcm in 1993 outside the former Soviet Union. Kazakhstan's oil reserves are estimated at 16 billion barrels. The crude oil distribution system in the former USSR was highly integrated and centrally directed as in other sectors. Like many other former all Union functions, it was organized without any concern for the republic's borders. For example, there exist no transfer facilities, such as measuring devices or tank farms, at the border crossings. One result of this is that data on inter-republic oil flows are quite limited and unreliable ${ }^{23}$.

It is estimated that oil production in the NIS will remain below $8 \mathrm{mn}$ barrels per day until the mid-1990s. Domestic consumption is expected to follow a similar pattern, allowing exports from the NIS to remain at approximately their current level of $2.2 \mathrm{mn}$ $\mathrm{b} / \mathrm{d}$ (of this, $1.7 \mathrm{mn} \mathrm{b} / \mathrm{d}$ is exported by Russia) ${ }^{24}$, even though the crude production fell to $7.8 \mathrm{mn} \mathrm{b} / \mathrm{d}$ in 1993 from $9 \mathrm{mn}$. The fact that Russian exports to destinations outside the republics and other former East Bloc nations rose more sharply than expected in 1993 exacerbated a glutted oil market and contributed to the drop in the world oil prices. NIS natural gas consumption is also expected to continue expanding and gas exports to Western and Eastern Europe are forecast to grow over the period to 2010. Given the expected rise in gas demand in Western Europe, the NIS are likely to be more important as gas producers to Europe than as oil producers. In fart, gas exports may become as important as oil exports for the NIS in terms of foreign currency earnings.

However, on the assumption that the improved economic incentives - through greater access to the hard currency export market which was granted to Russian producers in 1993 - are maintained in future years, it is expected that declining production van be stabilized by 1995 at about $7.5 \mathrm{mn} \mathrm{b/d}$, from fields already in production in 1992. This would represent a $40 \%$ decline from the peak of $12.5 \mathrm{mn} \mathrm{b} / \mathrm{d}$ in 1987 and 1988, according to the IEA estimates ${ }^{25}$. The extensive known and potential reserve base in Russia is expected to support a steady net increase in NIS production from the late 1990s onwards, slightly exceeding $10 \mathrm{mn}$ b/d in 2010, still well below the historical peak of 1987-88. Production in non-Russian republics, primarily Kazakhstan and Azerbaijan, is likely to rise faster than Russian output between 1995 and 2000, reaching $1.5 \mathrm{mn} \mathrm{b/d}$ (that is, $17.5 \%$ of NIS production), by the turn of the century, compared to $1.1 \mathrm{mn} \mathrm{b} / \mathrm{d}$ (under 10\%) in 1990. The NIS are the mort gas intensive region of the world, with gas accounting for nearly $40 \%$ of its primary energy consumption. It might be useful to highlight the basic features of the current energy situation in the Eurasian economies, borrowing from various IEA assessments:

39 -- a high dependency on a single energy source and the need to improve its use as well as identify energy alternatives to meet growing electricity demand;

40 -- a high dependency on a single foreign supplier of oil and natural gas;

41 -- weak management structures and inefficient use of energy, not only for power generation and other energy industries, but by industries such as steel and cement which are themselves in urgent need of modernization;

42 -- unacceptable levels of pollution and other environmental consequences of energy production and consumption, including problems of nuclear safety; and -- artificially 
low energy prises, which, while on the whole, higher now than last year, still do not reflect world market.

Political wrangling, which followed the Soviet disintegration, contributed its share to this bleak energy situation. The moves towards political independence from Russia by the Eurasian republics have had to be paid for at a high economic price. New trade and payment barriers have deprived the region of the full benefit of comparative trade advantages of each republic. Under these circumstances, the integrated system of oil and gas pipelines, as well as the electric power system, suffered disruptions and higher operational and capital costs. In awareness of these dangers, energy officials from Russia and the other republics tried to maintain as much co-operation as possible. In early 1992 the governments of Russia, the Ukraine and Belarus decided to form a joint stock company for inter-republican gas movements. All the former Soviet republics, with the exception of Turkmenistan, Latvia and Estonia, have applied for membership. In March 1993 top officials from the 12 republics formed a new "Inter-Governmental Council for Oil and Gas" in the Siberian town of Surgut with the aim of improving cooperation in oil and gas production, transport, pricing and investment. The Surgut conference, although it failed to resolve all contentious issues, at least appeared to recognize the high degree of interdependence that exists between the republics. In terms of natural gas, for example, the Ukraine depends on Russian gas for most of its consumption, while $90 \%$ of Russian gas must pass through the Ukraine.

The interdependent nature of the former Soviet gas and oil industries suggests that a compromise solution would he in the best interests of all parties Involved. However, critical questions on prices and transit rights still remain to be resolved. Increasingly, economic relations among the former Soviet republics continue to be dominated by issues surrounding the supply of fuels and electricity particularly given the trend towards liberalized energy prises internally, as well as the prospect that energy imports will be settled in convertible currency. Economic interdependence among the republics, particularly in the energy sector, proved to be a key element in the desire of many republics for some type of cohesion in the post-Soviet period, reflected in the formation of the CIS. The possible break-up of the CIS structure will disrupt entire energy system, including the flow of crude oil and gas over the territory of the former Soviet Union. Taking advantage of its relatively strong position, Russia wants to retain its final say over all CIS energy issues, holding in its hand a Sword of Damocles over the heads of other republics - an attitude, which give rise to fears of the possible revival of Russian imperialism in the region. The dispute between Russia and the Ukraine is particularly illustrative in this respect. Kazakhstan bas recently been subjected to strong political and economic pressure from Russia, which has demanded an equity share in Kazakhstan's giant Karachaganak natural gas field and is also laid to be seeking a stake in the rich Tenghiz oilfield ${ }^{26}$. The latest attempt by Russia to prevent Western companies from investing in Azerbaijan oil industry was detailed in an 28 April letter from its Foreign Ministry in which it demanded the right to reject Caspian Sea oil projects that its former Soviet neighbors are negotiating. It appears that the Eurasian states are coming to a point, where the avoidance of such a mutually harmful confrontation in the field of energy may not be easy.

Private and government backed energy investment in the NIS area in 1992 remained, at $\$ 150 \mathrm{mn}$, fairly insignificant. Both rides recognize that the oil sector is the most urgent area for foreign co-operation and investment. However, in the absence of a sound legal 
basis for such undertakings, foreign involvement did not go beyond relatively small pilot projects and feasibility studies. Joint ventures in oil production produced 5 mort in 1992 and were expected to rise to 10 mort in 1993. The World Bank, the EBRD and the US and Japanese Export-Import Banks are now discussing the first loans for the oil sector in Russia, Kazakhstan and Azerbaijan. The World Bank reports, in a new study ${ }^{27}$, a "radical shift in the pattern of external financing flows to developing countries in the early 1990s, from debt to equity financing and from bank to non-bank sources. Commercial bank loans have been replaced by bond and equity portfolio flows and greater foreign direct investment". Meanwhile, the major oil companies will continue to be largely self-financing. Despite self-financing and the shift away from debt financing, the view that financing is the new bottleneck in energy projects has many followers. In short, the world is resource rich, but capital short. Oil producers will therefore increasingly have to seek non-traditional sources of finance. Many oil and gas projects are competing with one another for a limited international money pool. In the final analysis, money will no doubt flow to the most profitable and safe energy investments. Since the over-intensive development policies pursued by the central government created severe environmental problems in all the Eurasian republics and unbearable strains were placed on the fragile ecological balance of the region, which led to various forms of dysfunction, environment-related investment financing is also becoming important.

Other Countries in the Eurasian Energy Puzzle

Iran throws its full weight behind Eurasia's oil and gas deals for its perceived regional ambitions. It offers them its energy technology \& experience and geography. The Iranian Foreign Minister, Mr. Ali Akbar Velayati, visited Central Asia's major capitals several times, trying to finalize agreements for exporting oil, gas and other commodities through Iranian ports. To lure this business, Iran promised to spend $\$ 1.5$ bn to complete a railroad between the Caspian Sea and the Persian Gulf and is said to be talking to some Western bankers about financing several new oil and gas pipelines. Iran's Finance Minister, Mr. Mohsen Nourbakhsh, estimates an annual trade of $\$ 10$ bn with the former Soviet republics once the new facilities are built ${ }^{28}$. Iran, exploiting its geography advantages, drags its feet in allowing Turkish trucks to cross its territory on their way to Central Asia, and gives mixed signals on whether it will ever agree to accommodate an Azerbaijan-Turkey pipeline ${ }^{29}$ - even if the Western (basically the US) objection will be overcome to a cross-Iran route. Iran is being portrayed as a countryweight to Ankara's growing influence in the region, while Ankara feels it necessary to underline that it is not in competition for regional primacy with any country. However, there are recent assertions that, in the face of an increasingly hostile Russia, starting to flex its still considerable muscles in Central Asia and the Caucasus, Turkey and Iran may be burying their differences and a convergence of strategic interests is emerging. A there-day official visit by the Iranian Vice-President, Mr. Hasan Hahihi, in December 1993, resulted in a series of agreements ${ }^{30}$ : agreement was reached in principle on a tripartite meeting between Iran, Turkmenistan and Turkey about transporting natural gas to Europe via Turkey; the extension of the Trans-European Motorway network as far as Iran; the lifting of obstructions facing Turkish trucks carrying goods to Central Asia via Iran; and building a railway service between Lake Van and Iran and Central Asia. summit conference of the Caspian Sea leaders, which led to the announcement of a 
Caspian trade grouping, incorporating all the riparian states. Aware of the importance of energy in the region, Iran moved fast to conclude energy deals with most of the former Soviet states early in 1993, including separate initial agreements with the Ukraine and Turkmenistan to build pipelines in order to export Iranian and Turkmen gas to Europe. As part of its overall strategy, Iran also agreed in April 1992 to supply four to five million tones of crude oil and $25 \mathrm{bcm}$ of gas each year to the Ukraine. Azerbaijan, too, wants to buy three to four bcm of gas a year from Iran to offset ruts from Turkmenistan.

Tehran is planning to modernize all its major ports in what appears to be part of its plan to become the gateway to the republics of Central Asia. In 1992 the government spent about $\$ 22 \mathrm{mn}$ to expand and renovate the country's ports ${ }^{31}$. Observers indicate that if Iran succeeds in its bid to act as a doorway to the republics, it stands to gain significant revenues from goods passing through its territory. Tehran bas been negotiating an agreement to handle shipping to Kazakhstan, the largest and richest of the Central Asian republics: the two countries already agreed to begin work on linking their railroad networks for facilitating the transportation of cargo to, and from, the Gulf port of Bandar Abbas.

The decision by Azerbaijan to offer Iran a quarter of its 20 percent overall share in the $\$ 7.4$ billion project to develop Azeri oil fields in the Caspian Sea - reportedly in exchange for providing financing and for counter-balancing Russia - bas sent shock waves through the Western consortium members. Iran agreed to fund energy projects in the Azerbaijani enclave of Nakhichevan as part of this agreement with Baku. Iran is also to fund an oil pipeline construction project there ${ }^{32}$, build a refinery with an annual capacity of 500.000 tones and an electricity system.

Tehran was one of the first countries setting up air links with Azerbaijan, Turkmenistan, Uzbekistan and Kazakhstan and is now in the process of integrating road and rail networks in an ambitious drive to link the region with the Gulf and to international shipping ${ }^{33}$. Iranian strategists are well cognizant of the fact that whoever provides a transit route will have greater influence over the course of events in that region. Iran is reportedly campaigning for the establishment of an international organization of producers and exporters of natural gas along lines of the OPEC. The creation of an alliance led by Iran of oil producing countries from the Caspian Sea region is also under consideration.

51 It appears that Japan is yet to fully flex its economic muscles in Eurasia, although several Japanese companies already started operating, on a relatively small scale, in the region. The Japanese National Oil Corporation announced that it would launch a feasibility study for the commercial production of oil and natural gas in the Central Asian republics. Seeking a stable alternative to Middle Eastern oil, the corporation hopes to obtain drilling rights and establish a large-scale joint venture with local, Japanese and major international oil companies ${ }^{34}$. Japan is also considering how to cope with the problem of transporting natural gas and oil from Central Asia to Japan. One plan would be to export oil and natural gas to other former Soviet republics or European countries and then swap them for oil and gas produced closer to Japan, as in Southeast Asia. Japan's first attempts to explore its interest in the region dates bock to May 1992, when the then Foreign Minister, Mr. Michio Watanabe, visited the region. On a follow-up mission, a high-level Finance Ministry delegation toured the region in October 1992. Business groups followed suit. 

officials returned from the region impressed by cultural affinities. Japan's current strategy towards Eurasia dues not seem clearly defined. It is loosely coordinated, with different ministries pursuing separate agendas, though the Foreign Ministry seems to be in the lead. But Tokyo nonetheless took a series of steps that set the stage for becoming the dominant aid donor to the region. A key decision came in December 1992 when Japan managed to put the five Central Asian republics on the Development Assistance Committee (DAC) list of the OECD. The DAC is a group of Western donor countries, which together provide more than $\$ 75$ bn (1993) worth of official development assistance to developing countries. It will now be possible for Tokyo to register its assistance flows to the region as official development aid. Japan has also been leading a drive to admit the Eurasian republics to the Asian Development Bank, even though they are already members of the EBRD. Reports indicate that Japan is about to complete its drive to open embassies in all of these republics ${ }^{35}$.

Japan's Ministry of International Trade and Industry (MIT[), in a white paper on energy policies $^{36}$, noted rising opportunities for oil development for Japanese oil exploration companies as a result of open policies adopted by these countries. However, Japanese upstream companies continue to lag behind major Western oil companies in terms of the number (if concessions, funds and technology because they have been in existence for a shorter period of time and act slowly \& overcautiously. In articulating a future energy policy, MITI posits that natural gas should be established as the basic of Japanese energy source with a view to cutting its dependency on oil and reducing the emission of harmful gases. The Japanese Prime Minister, Mr. Hosokawa, made a proposal during the APEC Seattle meeting in November 1993 to the effect that APEC should devise an Action Plan to address the general "tripartite" relationship between the three Es, namely: economic growth, environment and energy security. The Action Plan was approved at APEC's Bogor Summit in November 1994.

Central Asian natural resources and China's Tarim Basin figure prominently in any Japanese strategy towards Eurasia. According to press reports, there are some preliminary thoughts on transporting Central Asian oil and gas, via China, to Japan. The "Silk Route" energy project chat involves Japan, China and Eurasia is a mixture of energy politics and economics. At the present time, Japan is measuring the maximum benefit the country can secure, by either : (i) helping Russian Far East oil and gas development; or (ii) by supporting Turkmenistan gas development along with China's Tarim Basin oil and gas development. In effect, the Silk Route projects lifeline will ultimately depend on Japanese financing. White the decision will be a market-oriented one, political consideration will be fully reflected as well. A casual reader of Japanese affairs may be forgiven for thinking that it is not only on account of sources of energy that Tokyo is taking a keen interest in the Eurasian world -- strategic concerns to counterbalance two countries, namely Russia and China, through active engagement in the region, as well as cultural affinities all bear a considerable impact upon the current Japanese approach vis-a-vis this part of the globe.

56 Over the course of the next decade, China is expected to out-perform the economic achievements of the 'Arian Tigers' by a substantial margin. Development of the country's energy resources will therefore be an urgent and essential task if the momentum for such an economic drive is to be maintained. Much has been written in

Cahiers d'études sur la Méditerranée orientale et le monde turco-iranien, 19 | 1995 
early 1980s about China's emergence as a potential oil power. Comparisons have ranged from those that pictured China as another Middle East with a Middle East-like impact on future global oil markets, to more modest images of an oil-producing country that can meet its rapidly expanding domestic needs through the 1990s and still have some oil for export to its neighbors, particularly Japan. Yet, to fulfil even the latter prediction, China will have to surmount a series of substantial political, financial and technical obstacles ${ }^{37}$. China is today under increasing pressure to make significant new oil discoveries if it is to avoid, in such a high growth period, becoming a net crude oil importer in the nid-1990x, or perhaps even before. Its proven reserves at the end of 1980 stood at 3.2 billion tones or 24 billion barrels. However, estimates of proven and potential reserves vary, but mort China experts believe the country has a maximum of 5.3 billion tones ( 39 billion barrels) in onshore reserves and around 4 billion tones ( 29 bn barrels) in offshore reserves, giving a total of 9.3 bn tones ( 68 bn barrels). In 1991, China's oil production reached an estimated $137 \mathrm{mmt}$. Customs figures show that China exported $19.43 \mathrm{mmt}$ of crude oil in 1993, down from $21.51 \mathrm{mmt}$ in 1992 and imported $15.64 \mathrm{mmt}$, down from $11.36 \mathrm{mmt}^{38}$.

The Chinese government announced that its GNP growth of about $10 \%$ in 1994 would push up demand for oil and oil products which could not be met by local output. So the opportunity should be taken with oil prices currently at their five-year low to import a large quantity of crude and develop its petrochemical industry. it has already become a net importer in 1994. In the longer term (beyond the year 2000), the future of China's oil industries lies in the north-west regions adjacent to the borders of the Eurasian republics. Recent exploration for oil in the Tarim Basin in the far western Muslimpopulated Xinjiang-Uygur Autonomous region yielded significant finds. Extensive seismic surveys, conducted over the past few years by foreign contractors including the BP, NIPPON, ITOCHU, MITSUBISHI and MITSUI revealed many structures scattered over this vast area, including some of remarkable size. One of them, the Tazhong, in which oil was found in 1989, is the largest in China, covering an area of $12 \mathrm{mn}$ acres. Recognizing the fart that foreign investment and technology will be necessary in order to achieve their economic aims and to make China self supporting in oil, the Chinese government adopted a more open policy and international bidding was already opened for the there massive prospects in the west, mainly the Junggar, Turpan and Tarim basins. The first round of bidding attracted 68 foreign firms from 17 countries. These regions together produced $8.77 \mathrm{mmt}$ of oil in 1992, one $\mathrm{mmt}$ up on 1991, plus $700 \mathrm{mcm}$ of gas.

The potential for increasing production is immense, bearing in mind the fact that known reserves of those basins come to nearly 10 billion tones of oil ${ }^{39}$. (Chinese geologists estimated that the geological reserves of the Basin could be as much as $74 \mathrm{bn}$ barrels of oil and 7.9 trillion $\mathrm{cm}$ of natural gas ${ }^{40}$ ). There are also rumors that China saved the hest blocks on the Tarim Basin for itself, offering only the less promising ones to western companies. As already mentioned, there exists a Japanese proposal to run a pipeline all the way through the Kazakhstan border to the eastern seaboard of China, which would be $6.500 \mathrm{~km}$ long. Its feasibility is still under consideration. There is evidence that this could be of interest to Kazakhstan and Turkmenistan, both seeking alternative routes to their gas exports. China bas the potential to swallow a large portion of gas and oil from Eurasia. Transporting the Tarim oil and gas on a Eurasian pipeline to the international markets is also under serious consideration. Given this situation and its known geo-strategic interests in Eurasia, it would not be an 
exaggeration if one argued that China, a major player in the region, will continue to take an increasingly strong interest in the Eurasian energy prospects and do the best it can to shape the course of events there. In 1992 the presidents of Kazakhstan, Uzbekistan, Turkmenistan and Kyrgyzstan all visited Beijing one alter another and, in return, the Chinese Premier, Mr. Li Peng, toured all the Central Asian capitals in April 1993 to intensify co-operation with their "new" neighbors. In his speeches he regularly affirmed China's interest in stability and security in the region. To respond to China's security concerns, President Nazarbayev explicitly committed himself to preventing advocates of an "East Turkestan Republic" from working against China and interfering in Xinjiang from the territory of Kazakhstan ${ }^{41}$.

We should not pass without acknowledging such important actors in the Eurasian energy puzzle as Pakistan, Afghanistan ${ }^{42}$, India and South Korea, which proved difficult for us to cover properly due to the lack of sufficient information about their role in the region's energy business.

Turkey's Pipeline Diplomacy Or Pipedreams in Eurasia?

Seizing the opportunities and coping with the challenges in Eurasia require the best of geopolitical analysis, market intelligence, skill in cultural adaptation and an effective local partner. But, in some cases, success may depend on a far-sighted strategic alliance. This brings us to Turkey, a country that is not only situated at the crossroads of Europe, Western Asia, the Middle East the Caucasus and North Africa, but is also at the junctions of various new currents and different civilizations. From Brussels, Turkey is still a newly industrializing country with many Domestic problems, well behind the economic and political development of the EU; but seen from Tashkent or Baku, it is a dynamic regional power. Turkey's presence in Eurasia has been strongly felt since the demise of the Soviet Empire in many areas including the energy sector.

61 In recent years, Turkey bas achieved record economic growth - in 1993, its GDP grew by over 7\%, despite the long-standing recession in Europe, Economic growth meant surging demand for energy, notably oil and natural gas, Energy demand is forecast to soar by $148 \%$ from a projected 62.3 million tones of energy (TOE). in 1994 to $155 \mathrm{mn}$ toe in 2010, according to the Turkish Ministry of Energy. This will be met largely by a rapid increase in imports of natural gas, and an ambitious power station construction program. Its ten-year energy investment program requires an investment of $\$ 32$ billion, which will be financed through privatization of existing energy utilities ${ }^{43}$. Turkey's heavy dependence on oil imports will increase radically by 2010. Domestic crude output of 4.1 million tones met only $16.8 \%$ of demand in 1993. On the basin of current known reserves, it will dwindle to 299,000 tones in 2010 (most rapidly between 2003 and 2010), sufficient only to meet $0.75 \%$ of projected total demand of 39.6 million tones ${ }^{44}$,unless major new reserves are discovered. The national oil company, TPAO, produces just over three-quarters of the total, while foreign operators, such as Shell and Mobil, produce the rest. Domestic production is likely to deteriorate in the shorter term because of the increase in separatist terrorist activities in the southeastern region of the country. In 1992, oil provided $46.6 \%$ of the total demand and gas's share rose to $8.2 \%$ from 1991's 7.8\%. In 1993, the country imported, according to preliminary figures, some $19.65 \mathrm{mmt}$ of crude oil, up somewhat on 1992 as indigenous production continued to drop. Demand for imported natural gas is projected to increase from around $4.6 \mathrm{bcm}$ in 1992 to $30 \mathrm{bcm}$ in 2010, with the prime consumers expected to be industry and power plants. Within a couple of years, gas should be providing $15 \%{ }^{45}$ of primary energy 
demand, double that of its contribution three years ago. Deliveries already lined up from Russia, Qatar and Algeria; more could follow if new transit lines from Turkmenistan were established. Thus, a reduced share for oil is anticipated in total energy consumption. Fuel oil is giving way to gas and will increasingly lose market share as new hydro-electric and coal-fired power plants come into use. To meet the growing energy demand, the government has mapped out an ambitious power station construction program up to 2010, comprising 47 thermal stations, 100 hydro-electric plants and two nuclear power station.

Planners in Ankara claim that, besides being a major energy importer itself, Turkey could become a viable bridge for the East-West trade in energy, such as oil and gas from Central Asia, the Caucasus and the Middle East bound for Europe, and provide an oil refining center for the EU, comparable with those of Italy and Spain. Spain. Ankara is also trying to get help from the US, the EU, Japan and the rich Gulf Co-operation Council states in making the Black Sea zone a viable common market, with Turkey thus having important advantages as a transit route for all kinds of products and services. Turkey has some attractions for Western oil \& gas companies, exploration and production aside. In particular, the country is increasingly perceived as a jumping-off point for investment and trade activities in the Eurasian republics, many of which offer promising oil and gas prospects as highlighted earlier. Communications with these countries are relatively good and the Turkish government has made efforts to cement economic as well as political ties with these republics. The state-owned corporations, namely TPAO and BOTAS, have been employed as new instruments of Turkey's active energy diplomacy. Turks already signed various energy accords with Kazakhstan, Azerbaijan and Turkmenistan. For centuries, Turkey has been a hub between Europe and Asia and today she wants to serve as a trans-continental bridge. When it was just a question of providing an oil outlet for Iraq, there was no problem; then, Iran entered the scene, with the idea of sending gas through Turkey into Europe - a situation which calls for as delicate a piece of diplomatic manoeuvering as anything dreamed up at the height of the Byzantine Empire. The Turkish contribution has therefore become an important part of any plan for transporting the Eurasian oil and gas to Europe. The United States has notified several governments in the region that it would endorse construction of a pipeline through Turkey to carry future oil production from the Caspian region. A similar situation may arise as regards the Middle Eastern gas, too, when the Arab-lsraeli peace prevails eventually in the region.

Transporting Eurasian Oil \& Gas to Europe

Strange things are happening in the world of pipeline politics as a result of the continued political and military uncertainties in Central Asia, the Caucasus and the Balkans. Efforts to find new alternative export routes for crude oil from the Eurasian republics that would avoid Russia now appear to be in abeyance. The current network of oil and natural gas pipelines that serves the former Soviet Union is immense. The Soviet Union had built up an integrated gas supply network stretching over a distance of some $215.000 \mathrm{~km}^{46}$, more than half of which is made up of large diameter trunklines. The Soviet pipeline system was designed to transport some $800 \mathrm{mmt}$ of crude oil annually (about $16 \mathrm{mn} \mathrm{b} / \mathrm{d}$ ), with an export capacity of around $124 \mathrm{mmt}(2.5 \mathrm{mn} \mathrm{b} / \mathrm{d}$ ). The bulk of the system was laid during the last two decades, but pipelines are falling to survive anywhere near as long as their target 25-year lifespan. In Russia alone, 6.500 $\mathrm{km}$ of line and compressors need reconstruction. The single mort important reason for this widespread decay is that the Soviets laid pipelines without corrosion protection ${ }^{47}$. 
So, for the West, the construction of new gas pipelines from Eurasia seems to be one of the priority issues.

Crude oil trunklines stretch over a distance of more than $\quad 60.000 \mathrm{~km}^{48}$, including sections of the system that run into former COMECON countries in Eastern and Central Europe. The continued closure of the Adria pipeline, which has not been operational since September 1991 as a result of war in former Yugoslavia, thwarted the initial efforts of Hungary, the Czech Republic and Slovakia to buy oil from other sources. Poland is having the greatest success diversifying supply routes, including shipping Iranian crude via Gdansk to its inland Plock refinery, which used to rely solely on Soviet crude deliveries through the Druzhba pipeline. Poland has gone from near total dependence on Russian oil in 1989 to a situation, where it is now purchasing nearly two-thirds of its import needs from other suppliers. In terms of gas trade, Eastern Europe still does not have any sources of supply other than the former Soviet Union. It has, however, decreased imports from Russia by $15 \%$ between 1989 and 1992. Since the bulk of the region's oil and gas originates from the Russian fields, the main web pipelines is concentrated on Russian territory.

Unfortunately, much of the system is old and in urgent need of rehabilitation, or in some cases, of complete replacement. Even the more recent additions system often require immediate repair, as they have been built too quickly and without necessary insulation. Accidents to pipelines are frequent, causing damage to the environment and disruption to the economic activities. Several banks, including the EBRD, the World Bank and investment banks such as JP Morgan and Japan's Daiwa showed interest in participating in the rehabilitation and expansion of the Russian natural gas transmission network. Huge amounts of capital will be needed to finance the construction of new export lines planned for Western Siberia and the Russian Far East; but finding foreign investors and lenders for oil pipelines will probably be very difficult, as long as confusion continues about the ownership of oil resources and the most economical and politically stable route.

The Eurasian republics with large oil and gas resources of their own are no wonder in a hurry to find new ways to move their oil and gas quickly and safely to world markets. Republics with fewer energy resources are also

exploring new transport possibilities as a means of reducing dependence on the increasingly unreliable Russian oil and gas supplies, particularly after the Zhirinovsky Phenomenon caused widespread discomfort in the former Soviet sphere. 1t seems that pipeline plans in the NIS will continue to proliferate as the political situation becomes more complex. To a large extent they are not only planned in anticipation of higher export demand, but basically as alternative routes avoiding certain transit countries which could potentially create political problems.

Since domestic funds are not available, projects which can find foreign co-financing have the best chances of success. But foreign investors need to be convinced that export demand will be growing in the longer run and/or that the cost for alternative pipelines are a premium worth paying for enhanced security of oil and gas supplies. To find foreign funds for new oil pipelines is difficult. Given the size and flexibility of the world oil market, long-term supply security considerations are hard to sell to Western oil buyers. Funds can only come from foreign companies having a considerable share in local production. As long as these shares are as small as they are because of the legal and political risks perceived, foreign involvement in oil pipelines is bound to be 
insignificant as well. Only if the risks can be eliminated to a large extent, would foreign oil company participation in new oil pipelines reach, according to some optimistic forecast, up to $\$ 10 \mathrm{bn}$. The international oil and gas industry is already acutely aware that companies involved in major projects need to ensure a way out of the former Soviet Union for their oil and gas production to be viable. Oil output from Chevron Corp.'s giant Tenghiz development in Kazakhstan bas been throttled back because of inadequate pipeline facilities. A recently agreed-upon $\$ 9$ billion petroleum project in Azerbaijan also needs to settle on a pipeline route before a western consortium led by British Petroleum Co. and Amoco Corp. will begin major investment and development. However, negotiating to invest billions of dollars in new pipelines also is difficult in a region fraught with political uncertainty. Western oil companies have sometimes found themselves competing with domestic companies, who either seek control of transport facilities or oppose them ${ }^{49}$. Moreover, Western companies have found that they have been expected to make most of the investment in return for a less-than-proportional stake in the facilities (as in the Chevron vs Caspian Pipeline Consortium case).

At first sight, the break-up of the USSR appeared to be an answer to Turkey's prayers. The Eurasian states have a great deal in common with Turkey $^{50}$. Some share a common religion. They also share much of the same linguistic and ethnic heritage. Initially, high expectations were raised in the public that contacts between Turkey and the Eurasians would boom all of a sudden since the people of these republics were mostly of Turkic origin, speak a language similar to Turkish and had a common heritage of Islamic tradition. As time passed by, it became evident that these common values could not be the only factors in bolstering Turkey's political and economic ties with them. This does not of course mean that Turkey is not in a more advantageous position than many other countries. Turkey has encountered serious geographical problems as it has tried to develop relations with Eurasia. These have principally related to issues of access. Turkey has tried to neutralize this disadvantage of geography by seeking to develop non-terrestrial communications, putting emphasis on the development of a modern telecommunications network, and encouraging air transport routes. The prevailing view is that Ankara's role as a regional power can be enhanced only if Turkey properly assesses existing realities and predict future developments, refraining from mistakes that an over-emotional approach would causes ${ }^{51}$.

Agreement has been finally reached that Turkmen gas would transit Turkey on its way to markets in Western Europe via the Balkans. The Turkmen President, Mr. Saparmurad Niyazov, confirmed this accord in Davos and in Ankara last year. At a time when Turkey's natural gas needs are expected to hit $20 \mathrm{bcm}$ by the year 2000 with its production at $200 \mathrm{mcm}$, it is hardly surprising that Ankara bas intensified its negotiations with Russia ${ }^{52}$, its traditional supplier of natural gas, and has brought in new partners - namely, Georgia, Qatar and Turkmenistan for fresh supplies. Gas plans for Turkmenistan to Europe via Iran and Turkey are now on the back burner, just like the Azerbaijan pipeline deal, until the war in the former Yugoslavia is resolved to the satisfaction of all the parties. Representatives from Turkey, Iran, Turkmenistan, Kazakhstan and Turkey came together in Ankara in January 1995 to solve the problem of financing the project. But, at the end of the meeting, the members of the consortium remained as vague as ever on how the gas pipeline, the cost of which is estimated at between $\$ 5$ and $\$ 6 \mathrm{br}$, would be proneed. Aware of Western reservations about Iran, Turkey has proposed that it could take as the responsability of bringing the pipeline from Turkmenistan to Turkey via Iran. Ankara wants to assure coordination between 
Turkey, Iran and Turkmenistan, the "three main parties". An optional route exists through Bulgaria and Hungary, but for most suppliers a route around the north of the Black Sea would be even simpler. However, central and north European markets are already awash with gas offers (Russian, Dutch and Norwegian gas), while supplies from Central Asia would barely be competitive over such a long distance.

71 More attractive would be perhaps the southern option, through Greece, across the Ionian Sea and into Southern Europe via Italy. The problems there are partly technical, although the sea crossings are fairly straightforward; but politics once more may pose a problem, given the long-standing antipathy between Greece and Turkey. Nevertheless, Greece, too wants to become a transit center of an expanded energy network linking the EU with Iran and the former Soviet Union through Turkey. The Greek Industry Minister, Mr. Costas Simitis, said that "extending energy transport networks eastward would change Greece from a regional station to a basic strategic junction for Europe's energy system" 53 . He rightly fears that if Greece falls to place itself at the center of such a network, the link between Europe, Italy and the East would be made through its neighbors in the north and, as a result, "Greece would bear the political, economic and energy repercussions of being left out". Leaving aside the argument whether Greece could be a 'strategic junction' in energy transportation, we should consider the positive implications politically and economically of such co-operation on the traditionally tense relations between Turkey and Greece. In May 1994, at the initiative of the European Commission's SYNERGY program, Greece hosted a conference entitled "New Energy Realities in the Black Sea Region" and displayed keen interest in facilitating contacts between the EU and Eurasia. Energy co-operation bas been one of the most promising themes within the framework of the Black Sea Economic Co-operation. Given that Turkey's need for gas is predicted to rise to $12.5 \mathrm{bcm}$ a year by 1996 and, according to longer-term predictions, reach around $30.6 \mathrm{bcm}$ a year by 2010, it seems like there has been some considerable hard diplomatic bargaining behind the scenes and Russia did not make any attempt to block the construction of the $\$ 7$ billion Turkmen gas export line, via Iran and Turkey. With Turkey as the initial consumer until European demand justifies the extension of the line beyond Ankara, the line should be capable of delivering 10-15 bcm a year, perhaps rising to $28 \mathrm{bcm}$ a year ${ }^{54}$ thereafter, if justified.

Against this background, what is certain is that any energy route destined to Europe should consider crossing Turkish territory if it will be viable and, for the proposed gas trunkline to be profitable, according to experts, its capacity will have to be over $25 \mathrm{bcm}$ per year. This means shedding volume all the way, since no one country at the end of a 2.000-3.000 miles long pipeline is going to take that sort of supply risk. Turkey is seen as a first drop-off point. That will suit Ankara, switching its industry and housing to natural gas, if fees and prices were right. But both depend on sales further along the system and sales depend on security, something that will always be in doubt. More importantly, all the pipeline plans depend on resolution of political solutions to the age-old problems. Relations within and between the former Soviet republics must also be sorted out and the fighting in former Yugoslavia sits like a massive roadblock across everything. In the light of this situation, Mollet argues ${ }^{55}$ that "only a gambling banker is going to lend money for billion-dollar projects running through Eurasia". From the private investors' short-term commercial perspective, he may be right; but long-term energy security and geo-political considerations will certainly be at work in making the fateful assessment. 
Turkey's modest oil ventures know that they cannot compete against major oil multinational corporations. An early concession in Kazakhstan won by Turkey's BMB, a small engineering concern with little oil experience, fell flat and was hurriedly transferred to the state-owned TPAO. Turkey is still lobbying for a $\$ 1.5$ bn pipeline from the Caspian to the Mediterranean; but the preferred route through Armenia is blocked by hostility to Turkey and war with Azerbaijan, a spur through Iran might hit Western financing problems and a route through Georgia would be plagued by banditry. Turkey, seeking prestige, transit fees and access to Eurasian oil and gas, is set against plans to expand Trans-Russia pipelines to the Black Sea and made it clear that it will obstruct, by all means, any increase in supertanker traffic through the crowded Bosphorus Strait. The Turkish government argues that the Bosphorus would be further congested once a projected link between the Rhine and Danube rivers opens and in this case, the use of the Bosphorus for oil and natural gas shipments will increase the risk of sea accidents and will place navigation, environmental safety and physical security of Istanbul's 10 million inhabitants under grave threat. The passage of large tankers would effectively close the Straits to other shipping for long periods. It is worth noting that an average of 30.000 Turkish- and foreign-flagged ships sail through the Bosphorus and Dardanelles every year and $60 \%$ are tankers, carrying oil, oil derivatives and chemicals ${ }^{56}$. Even if the government bows to the foreign pressure, the Turkish environmentalists declared that they would move to the scene to block the passage of oil tankers through Istanbul.

BOTAş, the state-owned gas pipeline company, hopes that adding a Kazakh interest to the Trans-Caucasus pipeline will raise its capacity from a projected annual $25 \mathrm{mmt}$ to $40 \mathrm{mmt}$ and Turkmenistan, which currently favors a trans-Iranian export route for its gas, might add a gas pipeline as well. The idea is to achieve a transportation capacity of $40 \mathrm{bcm}$ per year from Turkmenistan to the Caucasus, the Balkans and European countries. It seems that Turkey already received positive answers from Bulgaria, Romania, Hungary and Austria regarding this project, which proposes a route starting from Ashkabad crossing the Caspian Sea, and going through Azerbaijan, Armenia and Turkey and then the countries mentioned above. In Austria, the pipeline would link with the European gas network. BOTAş considers the project in two stages : first, a pipeline and then, its twin. The first line has an estimated cost of $\$ 8.5 \mathrm{bn}$. The second should cost less, around $\$ 5 \mathrm{bn}$, since most of the infrastructural work and engineering would be carried out while constructing the first line. The $4.800 \mathrm{~km}$ route proposed by Turkey is the "shortest" connecting the rich Turkmen gas fields to the European markets ${ }^{57}$. Turkmenistan announced that it would be able to export $28 \mathrm{bcm}$ of natural gas in 1993 and is looking for alternative routes to the former Soviet gas network. On the other hand, since it shares a long border with Turkmenistan, Iran is also well positioned to play a role in carrying Turkmen gas to the Gulf over its territory. To reach the Indian Ocean via Pakistan is another alternative. These two alternative routes are mainly aimed at supplying the Japanese and other Southeast Asia-Pacific markets. However, the feasibility of such a route is very much in doubt for a variety of political and financial reasons. The route that Turkey proposes and that has to wait for a peaceful resolution of the conflict in the former Yugoslavia, is aimed exclusively at meeting Europe's future natural gas demand.

Looking at the present state of affairs, Western oil analysts assert that, with prospects of peace in the Caucasus still not in sight, claims by Turkey's leaders that the Eastern 
Mediterranean port of Iskenderun is about to become the world's Second Gulf, with oil and natural gas pouring south by pipeline from Azerbaijan and Central Asia to a major new energy outlet - with the producer countries, international energy giants and Turkey sharing the benefits - sound more like pipedreams than real prospects ${ }^{58}$. Is it realistic to jump to such a quick conclusion?

True, the initial pipeline planned to take Azerbaijani oil to the Mediterranean was supposed to pass through Armenia and Iran. If a reliable and enduring solution to the dispute between Azerbaijan and Armenia cannot be found, it is hard to see one exporting oil via the other. Under the present circumstances, the pipeline project via Iran remains the only option (preferred by Azerbaijan a, well); but it touches on the sensitive nerves of the Western investors. The BOTAş director-general, Mr. Hayrettin Uzun, said that the pipeline projects for transporting Caucasian and Central Asian oil to Europe had to be put shelved ${ }^{59}$ due to continuing political instability in the region. Does this mean that Turkey, Azerbaijan and the oil companies have to go back to square one and reconsider the 'unthinkable' alternatives of oil tankers queuing up in the Bosphorus or a pipeline diverted via Iran? Will the Eurasian republics simply seek outlets for their mineral wealth via Russia? Turks appear to have made a practical analysis of the current circumstances. There is a standstill in the pipeline project, but one thing has now become clear from the insistence by Mr. Uzun of BOTAS, who bas repeated: "We are not going to allow the use of the straits for large oil tankers as we cannot jeopardize Istanbul"60 and, in a bid to substantiate this warning and ignoring strong Russian protests, Turkey announced few days later new regulations on the passage through the Straits, which became operational from 1 July 1994.

Under these new regulations, tankers with harmful chemical loads, nuclear-powered vessels or ships with nuclear-related material need to request prior permission from the Turkish Ministry of Environment to pass through. A collision last year in the Straits between an oil tanker from Novorossiysk and a freighter demonstrated that the Turks' concerns appear well founded. Experts believe that Ankara now prepared the legal case to deny passage to large oil vessels through the Bosphorus, or delay them by requiring pilotage. Governments and producers must be aware that Ankara and particularly Turkish environment groups could make life difficult for unwanted tanker traffic. Delays tan cost huge sums of money. It is not only Russia, Azerbaijan and Kazakhstan that have to worry about the implications of such a Turkish action ${ }^{61}$. Bulgaria, Romania and the Ukraine, too, are all exploring Black Sea waters. One suggestion is that the problem could be solved by building a relatively short pipeline along the Bosphorus Straits and the Sea of Marmara. However, such a project would add considerably to the costs of the northern route and raise objections from Greece as tanker traffic would affect this time its islands in the Aegean. To bypass the Turkish Straits, the Russian government now insists on Kazakh crude being routed through Novorossiysk, across the Black Sea and thence via a pipeline crossing Bulgaria and ending up in Greece. On the other hand, Albania, Macedonia and Bulgaria signed a protocol to study the potential for a new pipeline to carry crude oil from the former Soviet Union to exit at Vlores on Albania's Adriatic toast. The planned Trans-Balkan pipeline, too, aims to bypass Turkey's congested Bosphorus exit from the Black Sea providing an alternative route, with a capacity to deliver $800.000 \mathrm{~b} / \mathrm{d}$ of crude $^{62}$.

A long-term measure would be to consider alternative oil transport routes from Eurasia to the open seas so as to cut clown on tanker traffic through the Turkish Straits and to 
enhance security of supplies. Mr. Sami Kohen, a diplomatic analyst, suggests that it may be possible to transport the Eurasian oil and gas to the Russian port of Novorossysk by pipeline, then to Samsun or any other port on Turkey's Black Sea toast and finally to Iskenderun via a pipeline crossing Anatolia. This alternative would have both advantages and disadvantages for Turkey and is not looked upon positively by key policy makers in Ankara. A Turkish pipeline is seen as serving not only the flow of Kazakhs, Azeri and Turkmen energy exports, but also as providing growing Russian exports with an alternative outlet. Under any circumstances, Turkey has been perceived as an important player in the Eurasian energy 'game' and it is certainly in the best interests of all the major players to co-operate in this positive sum game rather confront one another.

Whatever the obstacles and financial risks, they will eventually be overcome and a Caspian pipeline will be built because the hydro-carbon potential of Eurasia is tremendous, and it has to be shipped to the international markets. In fact the pipeline contest is not entirely a zero-sum game and the longer-term future point a twopipeline solution for two simple reasons. First, Kazakhstan, Azerbaijan and Turkmenistan find the prospect attractive of two pipelines destined to a northern Russian port on the Black Sea on the one hand, and a southern Turkish port on the Mediterranean on the other. None of these countries want to be completely dependent on Russia, yet each is hesitant (Kazakhstan more so) to rut Russia entirely out of the energy picture, risking a backlash. Second, the first project that emerges as the solid front-runner (for instance, the northern route of Kazakhstan) will pull capital away from the other (the Baku-Ceyhan route of Azerbaijan) and it will pick up momentum. Then, money will flow less easily to the second project. In this case, the producing country whose favored plan loses out will have a sort of second-cases status in the prevailing pipeline, with its needs subordinate to these of the other producer. One additional reason may be the worsening of the political and economic crisis in Russia. If Moscow falls to play a constructive role in the Caspian Pipeline Consortium and the regional authorities of Southern Russia become more ambitious vis-a-vis their own role in the project and if Azerbaijan reaches a stable settlement with Armenia, which recent reports indicate may now be within reach, then the Turkish pipeline will become the favored option. The Chechnya conflict, which rendered transit passage via Grozny unfeasible and the US political support extended to the Baku-Ceyhan route reinforced Ankara's hopes for its pipeline project.

Future Prospects

The task of adequately forecasting developments in the Eurasian region is more difficult than it was in the past when one could at least assume a stable structure. Political and economic instability has been the order of the day and energy is one important sector adversely affected by this situation. No country has been able to achieve, or tan logically expert to achieve, energy self-sufficiency in isolation from world markets. Energy security tomes, not from insular self-sufficiency, but from healthy energy trade. Sound markets are now understood to be the most certain source of secure energy supplies. The energy trade has evolved from a focus on long-term, fixed price, fixed volume and exclusive contracts, to a set of flexible arrangements whereby market participants are positioned to benefit from different and changing costs, from price changes, from shifts in supply or demand, and from new production techniques or other energy-related technologies. One of the more important things that the West can share at this stage with its Eurasian partners is precisely its 
experience in making this transition from less to more market-oriented trading patterns.

81 To effect the successful transformation of the energy-using and -producing sectors, the macro-economic framework must be structured to improve the investment climate and balance of payments pattern; a suitable institutional framework to facilitate a rapid market-determined supply response; autonomous and market-oriented energy-supply enterprises, preferably in the private sector; improved energy efficiency; promotion of foreign direct investment both in existing enterprises and in new ventures; a careful analysis of alternative trading options. Technical standards i.e. the quality of products and supply reliability must be improved; and a viable and sound infrastructure pipelines, transmission lines, transport and port facilities - must be established. A well balanced orchestration of such policy, institutional and investment actions should ultimately result in a considerable restructuring of the energy use and supply mix in the region. This would entail a decrease of the use of coal and an increase in the use and the exportation of oil and natural gas, particularly from Turkmenistan and Kazakhstan. The scenario would also involve increased trade among the countries of the region, as well as changes in the pattern of supply from other countries.

It is widely held that the key to a successful reform and development in Eurasia would be the speedy inflow of managerial resources, including know-how, licenses, working practices and management skill, from the West through foreign direct investment (FDI). Besides the framework conditions, such as non-discriminatory treatment of FDI, free remittance of earnings, protection of investments, transparent, stable laws and streamlined one-stop admission procedures, Western investors are after a good business environment, political and social stability, an efficient banking system, guaranteed land ownership or long-term leasehold by investors, an economically sustainable tax system and well developed infrastructure of telecommunications and transportation. If all the oil and gas resources are to be exploited and marketed, new pipelines will, in many cases, have to be constructed. At the same time, the world tanker fleet needs renewing. And, as demand for imported fuels increases in the West, new refineries will have to be built ${ }^{63}$. Western capital and technology must be introduced as quickly as possible to rebuild the oil and gas industries in the former Soviet republics. But although many joint ventures have been negotiated, few have actually got off the ground due to problems over resource rights, the absence of a legal framework for investment, inadequate tax systems, confrontation between central and local governments, political turmoil and other factors.

One important question remaining is how much energy finance will be needed and from where it will come. Investment in energy, especially hydrocarbon investment, is risky. The investment timeframe is long-term, the demand projections are uncertain, there can be sharp cyclical swings, taxes and other costs can increase unexpectedly and the political background can change dramatically over the course of the investment. Over the next 15 years, oil and gas companies estimate that they have to invest between $\$ 300-\$ 400$ billion in Europe to meet energy demand ${ }^{64}$. Between $\$ 985$ billion and \$1.6 trillion oil and gas investments are required worldwide to meet projected energy needs in the next decade. Commercial banks, supranational development batiks and the public capital markets will all play a part in raising these billions of dollars required. A number of foreign energy companies already jumped on the bandwagon to 
Central Asia and the Trans-Caucasus. They are comparing risks in this region with risks in Russia and elsewhere.

Typical risks in these countries include political instability, remoteness and difficulty of developing energy reserves in some regions, Jack of experience among local bureaucracies in doing business with Western companies, and ethnic or territorial disputes between neighbors. The risks in Russia are of the same range but its opportunities are comparatively vast: the energy resources of Russia are by far larger than those of Central Asia and Azerbaijan. However, while the latter countries are mostly landlocked and are largely a desert populated by more than 100 different communities, the Russian Federation has far bigger problems as well as huge risks. Risks and opportunities also range from local rivalries to regional blocs competing with one another. All in all, one can confidently argue that, for Western investors, Eurasia is a largely unexploited virgin land, where future gains will be more important than short-sighted risk calculations. Nevertheless, initial support must come from Western governments and multilateral banks. In facts, governments at present provide or broker the bulk of infrastructure financing: about $90 \%$ of financial flows for infrastructure are channelled through a government sponsor, which bears almost all project risks. Only then will private investors follow suit. Many foreign investors will hold back in mega-projects until multilateral agencies such as the Word Bank and the EBRD lead the way. In the final analysis, we believe that it is truly a win-win situation for both sides if emotions and short-term political considerations are restrained.

Final Word

The Eurasian nations are facing truly tough decisions in the next several years over their energy policy. They must carefully tread a balance along the thin line of politics and economics of oil and gas. They must become realistic in their investment plans. They must base their decisions on economic necessities and, above all, they must learn to live with each other and their neighbors with a view to joint projects which will enhance their future energy prospects. Bearing in mind the predominance of Russian oil and the current heavy infrastructural dependence of the Eurasians on their big northern neighbor, it would be appropriate to suggest that any sizeable investment and co-operation projects with the former Soviet republics be carefully coordinated, at least in the immediate future, with the Russian Federation ${ }^{65}$. This would ensure the smooth functioning and economic viability of such projects since the nature of the infrastructure such as refineries, crude and product pipelines, depots, terminals and maintenance, will require a relatively strong link to be maintained between Russia and other republics.

However, some quarters in the West are seriously concerned that a revival of Russian imperialism is in the offing. Russia and the West may be once again on a collision course $^{66}$. The issue is the threatening Russian policy towards the other states of the former Soviet Union: are the Russians entitled to meddle there or are they not? President Yeltsin explicitly asked the U.N. "to grant Russia special powers as a guarantor of peace and stability in the former countries of the USSR". This is a 'Monroesky' doctrine, a declaration that in the 21st century the former Soviet Union is Russia's sphere of influence, just as in the 19th century James Monroe declared that the Americas were the United States's. More recently, one of the main issues at the Budapest meeting of the CSCE was Russia's demand that the 'near abroad', as it patronisingly calls its ex-Soviet neighbors, should in effect be recognized as a Russian 
sphere of influence. Russia wanted the CSCE's western members to let the Commonwealth of Independent States act as the region's peacekeeping force. Since Russia dominates the CIS, which encompasses 12 of the 15 former republics of the Soviet Union, that would have restored the Kremlin much of the power that it had in Brezhnev's day. The CSCE demurred, and instead decided that troops under its own control should be dispatched to Nagorno-Karabakh. The CSCE force will be the first international peacekeepers to be sent to the former Soviet Union. Over the past few months, Russian policy in the 'near abroad' has subtly shifted. According to The Economist ${ }^{67}$, the 'sabre-rattling' of involvement is ending, giving way to what might be called an arm-twisting federalism. Both policies aim to project Russian power. The difference is one of emphasis and means: the new policy stresses economic (particularly energy) pressure rather than military intervention, trade rather than destabilisation, a manipulation of local rivalries rather than a straight imposition of Russian will. Why Russia or some Russians are interfering in the affairs of the former Soviet republics is mot difficult to guess. No colonial power, from Darius to de Gaulle, has ever voluntarily and peacefully relinquished its previous sphere of influence and the crumbling of the Russian-led Soviet Empire is yet another case of painful decolonization ${ }^{68}$. Rosenfeld of The Washington Post ${ }^{69}$ believes that what is happening in Russia is not an advance to a post-Communist version of the Cold War, but a return to a pre-Communist version of a 19th century balance-of-power national -interest world. We see this in its internal debates on the traditional Westernizer-versus-Slavophile theme and in its policies in Europe, Bosnia, Iraq, Chechnya and the rest.

The Eurasian countries and their infant petro-economy are particularly vulnerable to a more aggressive Russian foreign policy ${ }^{70}$. The region, from the Black Sea to China's western borders, is threatened on various levels by the philosophy advocated by the socalled liberal democratic leader, Vladimir Zhirinovsky, whose neo-fascist party won a large bloc of seats in the December 1993 parliamentary elections. The revival of imperial and big power behaviors in Russia's relations with the other successor states can only produce additional friction because there is an almost natural reaction to a century-old experience of the non-Russian peoples of being mere object in Russia's imperial policy. The latest Russian military intervention in Chechnya, despite calls for peaceful settlement, fueled further fears elsewhere in the NIS area. Moscow insists that Central Asia and the Caucasus remain a strategic asset, an area from which it can exert influence over the oil-rich regions of the Caspian Sea and the Persian Gulf, as well as southern Europe. Russians are in turn worried about the still widespread phobia of 'Muslim fundamentalism', the spill-over of conflicts from the 'near abroad' into the Russian Federation, where 15 million Muslim believers inhabit, and the uncertain plight of the Russian minority living in Eurasia.

Given the inflammatory situation in the former Soviet geography, the responsibility of all those involved requires that the future of Eurasia is shaped as peacefully as possible. The West can help the new states on the territory of the former Soviet Union through a pro-active policy of cautious and balanced influence. The Eurasian republics should not be left on their own, but must be supported politically and economically in their efforts to develop new, alternative (other than Russian) links in opening up to the outside world. Only then will they be able to enjoy co-operative relationship with Russia on an equal footing. Otherwise, Russia might perceive the current indifference of the West to what happens in Tajikistan, Abkhazia, Ossetia, Trans-Dniester, Azerbaijan and Crimea as a "green light" to their self-declared sphere of influence. Reducing the historical 
semi-colonial dependence of the Eurasians on Moscow should be the first step in this direction. This would entail mobilizing the republics' indigenous natural and entrepreneurial resources, promoting foreign investment and trade, especially through the creation of logistical trade and transport corridors and encouraging them to help themselves. It is correct that the internal dynamics of the EU foreign policy-making and various constraints i.e. finances, conflicting national interests among member states, competition with other policy areas and geographical priorities (Eastern \& Central Europe and the Mediterranean), are currently holding back the development of an effective EU policy response towards Eurasia. But, at a time when there are quite a number of major external players in the region competing with each other, we believe that the EU cannot afford to stand idly on the sidelines or be indifferent economically and politically to this important geography. It should join forces with the regional countries in designing a political, economic and security strategy in which energy diplomacy is destined to play an increasingly important role. Such a strategy must also ensure strong support for the continuing transformation of Russia itself towards greater democracy and a free market economy. In terms of energy security, new investment opportunities, regional stability and security, it would be in the best interests of the EU to hammer out a longer-term strategy, instead of its current piecemeal and mainly commerce-driven approach, toward the Eurasian reality.

The moderating of oil nationalism is moving producing countries towards a more commercial approach to their natural resources. Oil is being seen more as an economic asset than a political asset. Nevertheless, there are still reasons to be skeptical about the security of energy supplies. The biggest threat to energy security comes from the possibility of oil once again being used as a weapon to achieve specific political objectives. Such a situation would be extremely conceivable should a dictator like Saddam Hussein expand his control over the region's oil fields or a succession of antiwestern Islamic parties come to power in oil-producing countries.

To prevent this happening, countries like Turkey, which is seen as a Western, secular, democratic, free market-oriented and bas special ties to the region and the West, are needed as ally partners in formulating and executing the overall Western strategy towards the Middle East and Eurasia. But Ankara frustrated by lack of sufficient support from the West is now underlining that its co-operation should not be taken for granted as in the part. In the post-Cold War era, energy will be one of the most important areas in which Turkey's future role in the international system will be determined. Recent geopolitical changes have placed Turkey at the epicenter of a new economic and political reality in Eurasia, and Turkey's policy of promoting Eurasia as a region of peace, stability and prosperity would be all the more effective and conclusive if supported by its Western partners. With the relative dynamism of the Turkish economy, these contacts may open up new possibilities for the EU countries, at the time of economic recession at home, to co-operate in joint ventures targeted at both Turkey's large 60 million-strong internal market and those of its regional partners. Triangular partnerships, including other countries in the Black Sea region and Central Asia, offer additional advantages which would reduce the risks of direct investment there. Turkish-led regional integration initiatives such as the Black Sea Economic Cooperation (BSEC) and the Economic Co-operation Organization (ECO), whose membership include most Eurasians, should also be considered in this context for joint efforts. 
91 Above all, Turkey has a broad strategy interest in securing the Caspian pipeline to Yumurtalik. This overriding political and economic interest has, according to some Western analysts, several components. First, the transit fees will leave Turkey with a significant portion of the rent generated by Caspian-area oil exports. Second, if Turkey establishes itself as the guarantor of Azerbaijan's and Kazakhstan's future oil wealth, its long-term influence in those countries will be solidified. Third, it would provide an extremely solid basis for long-term relations with the Turkic republics and guard against the possibility that Turkey could be shut out of the area by a revived and aggressive Russia, as it has been in the part. Fourth, Turkey does not want the Bosphorus to become a supertanker expressway in the middle of its largest city. Finally, Turkey's five oil refineries, which have over 250.000 bd in spare capacity, could also be fed by Caspian-area crude. Russia, too, would benefit from the alternative pipeline since spare would then be freed in Russia's export lines for extra Russian oil and gas. In a nutshell, geography, economics, diplomacy and culture are all inseparably linked in the Eurasian equation and now compels the West to adopt a multi-faceted approach in forging ties with Turkey and new market economies of Eurasia. The EU is currently faced with the difficult problem of achieving greater integration of Turkey into its institutional framework and, as Italian analyst Roberto Aliboni warns, must be careful not to assume that by giving Turkey an international 'Turkish' role it will necessarily be compatible with European interests. Hence it is important to underscore at every instance where mutual interests of Turkey and the EU converge as far as Eurasia is concerned.

We believe that the time has come for the West to make fundamental choices about dealings with the post-Soviet challenge. The new geopolitical situation arising from the collapse of the former enemy offers a mix of enormous opportunities and tremendous risks. The hard Tact is that the Eurasians will not be able to make a smooth transition on their own. The rate of progress in developing and transporting their energy resources will depend to a great extent on political stability and on how much help is provided from both private and public sources in the West. As Simes rightly points out, during ordinary times the politics of nations - particularly such great nations as Russia - can be only marginally affected from the outside. During periods of great transformation, however, with all their concomitant volatility and turmoil, input from abroad can make an enormous difference ${ }^{71}$. It is beyond doubt that the West in general and the EU in particular have great stakes in, and can influence, the final outcome. Energy is, in our judgement, the single most important area of co-operation in the postCold War Eurasia to which a meaningful, indeed self-serving, Western contribution needs to be injected at the earliest opportunity.

\section{NOTES}

1. Edward Krapels, "The Commanding Heights: International Oil In a Changed World", International Affairs, 1 (1993), p.71. 
2. Dev George, "Redefining the Middle East: New Countries, New Politics and New Activity", The Offshore Middle East Report, March 1992, p.25. The Western governments seem unwilling to put their strategic relationship with Russia at risk because of the Central Asia and Azerbaijan. See The Economist Foreign Report, 'Russian Pressure on Azerbaijan', 14 July 1994, pages 1-3, for an analysis of this attitude.

3. Alexander Sheindlin, "Energy in the Countries of the Former Soviet Union", Perspectives in Energy, 1991, Volume 1, p.449-458.

4. Rob Sobhani, "Russia Tests the US in Azerbaijan", The Wall Street Journal Europe, 18 June 1994.

5. James Clarke, "Oil-Gas Prospects of Central Asia and the Caucasus", Geopolitics of Energy, 1 December 1992, p.11.

6. Hugh Pope, "Turning Pipedreams Into A Rich Reality", The Independent, 1 June 1993.

7. "Seminar on East-West Energy Trade: Proceedings", Vienna 3-4 October 1991, OECD, Paris, 1992, p.76.

8. Hacene Mefti, "Energy Strategies For Tomorrow : Managing For Uncertainty", Energy Forum June 1993, p.7.

9. "Energy Policy: Commissioner Sets Out Future Policy Orientations", Europe Energy, No.410, 15 October 1993.

10. For two generations the underlying tension in the energy trade bas been between the Western oil companies, which basically represent the consumers of North America and Europe, and the principal producers of the Middle East. That will change. The main producers will still be in the Middle East because chat is where $70 \%$ of the world's oil is located. The skills of finding and extracting oil will remain in North America and Europe, but the demand will come mainly from Asia-Pacific and Latin America. According to reliable scenarios, in a 'high growth' case by 2020 energy use in the developing countries could account for as much as $60 \%$ of the world total, compared with $30 \%$ in the OECD area. When that happens, oil prices are liable to become as unpredictable as they were in the second hall of the 1970s.

11. "ECS: Draft Own Initiative Opinion On A EC Energy Policy", Europe Energy, No: 410, 15 October 1993.

12. Paul Mollet, "Energy Policy Creeps Up the EC Agenda", Petroleum Economist, October 1993, p.

17.

13. EU Strengthens Southern Ties", EC Energy Monthly, 23 November 1994, Issue 71, p.1.

14. "CEC Energy Policy Issues and the Energy Charter", a paper submitted by Mr. Christian Waeterloos, Head of Energy Policy Division of the EC Commission, to the IEA's Oil Market Orientation Seminar, Paris, 16-18 June 1993.

15. REUTER news dispatch, Brussels, 20 December 1993.

16. For a detailed analysis of the Charter Treaty from the EU perspective, see Europe Energy, No. 435, 25 November 1994, p. V 1-22.

17. "Energy Charter : First International Treaty Since Cold War", Europe Energy, No.431, September 30, 1994.

18. "The US says no method yet to ease objections to Europe Energy Charter", Knight-Ridder, New York, Pamela Conway, 19 December 1994.

19. Western Business Seen As Kazakhstan's Security Guarantee", London, Associated Press-DJ, 22 March 1994.

20. Marcello Colitti, "Oil and Gas in the CIS to the Year 2000", The Oxford Energy Forum, May 1992, London, p.4.

21. Randolf Granzer, "The 1992/1993 Energy Situation in the Former Soviet Union", Oil Market Orientation Seminar, 16-18 June 1993. 
22. "Russia's 1994 Oil Production", in Associated Press-DJ dispatch, Moscow, 20 December 1994.

23. Matthew J. Sagers and Milford B. Green, The Transportation of Soviet Energy Resources, Rowman and Littlefield, London, 1986, p.55.

24. Allanna Sullivan, "Russia Says It May Reduce Crude Exports By Up to 75 \%", Wall Street Journal Europe, 2 December 1993.

25. IEA World Energy Outlook, 1993, Paris, p. 19.

26. Steve LeVine, 'Kazakhs accuse Moscow of stopping oil exports', Financial Times, 28 June 1994.

27. "New Directions In Energy Finance", editorial essay, Petroleum Economist, June 1993, p.4.

28. Peter Waldman, "Great Game 1993: Iran Tries to Subvert Oil-Rich Azerbaijan, And So Far Is Falling", The Wall Street Journal, 1 June 1993.

29. Pierre Shammas, "Energy Co-operation in Central Asia : Global Perspective", a paper submitted to the International Conference on Energy Cooperation in Central Asia and the Caucasus, 1-2 September 1992, Tehran.

30. "Differences Buried As Russia Looms Large", Briefing, 27 December 1993, Issue 970, Ankara, p. 7.

31. "Iran Modernizes Ports In Bid to Become Gateway to Central Asia", Associated Press News Dispatch From Nicosia, The Turkish Daily News, 5 October 1993.

32. "Ankara taken aback by Baku's Caspian Oil Share Snub ", Briefing, 21 November 1994, Issue 1016, p.8.

33. "Iranian President Returns From His Tour", The Turkish Daily News, 30 October 1993.

34. "Japan Seeks Output of Oil, Gas in Central Asian States », The Yomiuri Shimbun, Tokyo, 31 March 1993.

35. Steven Brull, "With Oil and West's Appeals in Mind, Tokyo Plans Aid For Central Asia", Tokyo, International Herald Tribune, 16 December 1992.

36. "Japan's Energy Security", Associated Press/DJ, Tokyo, 2 July 1993.

37. Dr Mamdouh G. Salameh, "China's Oil Future : A Case for Radical Treatment", The Opec Review, Summer 1992, Vienna.

38. REUTER news dispatch, Beijing, 1 February 1994.

39. A.W. Jessup, "China Dragon Joins East Asia Tigers", The Geopolitics of Energy, 1 August 1993, p. 7.

40. "Tarim : Worldwide Hunt Leads Oil Prospects to China Savage Sands", International Herald Tribune, 22 March 1994.

41. China Aktuell, April 1994, p.392.

42. Regional tension over Afghanistan is important in terms of energy diplomacy as well. The Central Asian republics have resources and reasonably educated populations, but suffer the tyranny of vast distance from the outside world. Rail and road links to the east and the west are being improved, but the closest sea is the Indian Ocean via Afghanistan. Pakistan has a big interest in becoming a gateway (just like Turkey, Iran, Russia and China) to Central Asia for business from the rest of Asia, but while Afghanistan is unstable, little can happen on that front. See Philip Bowring, "Central Asia At Risk In Afghanistan", International Herald Tribune, 2 February 1994, p.6.

43. "Turkish Energy Regime", OPECNA File, October 1994, p.51. Passage finally in November 1994 of a fundamental privatization law in the Turkish parliament has raised hopes of speedy implementation of privatization in the Turkish power sector. First off will be the sale of ten large thermal power stations in 1995 to raise an estimated $\$ 5 \mathrm{bn}$. At present, the state dominates the power sector with a $92 \%$ share, the remainder largely accounted for by two private sector companies, Çukurova and Kepez Elektrik. 
44. "Turkey Seeks Means to Match Soaring Energy Demand", European Energy Report, 18 February 1994, 405/3.

45. Paul Mollet, "Oil Sector Heads For New Horizons in Turkey", Petroleum Economist, September 1993 , p.33.

46. Some $40.000 \mathrm{~km}$ of oil lines lie in Russia. Russian gas trunklines cover around $140.000 \mathrm{~km}$. From this tore, long extensions stretch out into former Soviet republics in the Baltics, Central Asia and the Caucasus, and Belarus and Ukraine.

47. Isabel Gorst, "Gas Colossus (Gazprom) Seeks New Bearings", The Petroleum Economist, June 1992, p.5.

48. Isabelle Gorst, "Former soviet Union: Pipeline Plans Proliferate" The Petroleum Economist, June 1993, p.6.

49. Bhushan Bahree, "Western Oil Firms Must Help Build Pipelines, Russia Says", The Wall Street Journal, 12 December 1994.

50. See Mehmet Öğütçü, 'Islam and the West: Can Turkey Bridge the Gap', Futures, volumes 26, $\mathrm{n}^{\circ} 8$, October 1994, Cambridge, pp. 811-829, for a discussion of Turkey's possible role as a bridge between Eurasia and the West.

51. Sami Kohen, "The Russian Factor in Central Asia", in Milliyet, 11 August 1993.

52. Russia alone is the biggest supplier of Turkish gas. A very important instrument in the TurcoRussian trade exchanges is the natural gas agreement, signed with the Soviet Union back in the mid-1980s. Under that agreement, now undertaken by Russia, Moscow uses a very substantial part of the foreign exchange Ankara pays for gas supplies for the imports of Turkish goods. Russia supplied $4.5 \mathrm{bcm}$ of natural gas in 1992 and supplies are expected to reach $5.5 \mathrm{bcm}$ in 1993. See "Turco-Russian Economic Relations : A Leap Forward", ANKA Review, 5 October 1993, p.9.

53. REUTER news dispatch, Athens, 1 February 1994.

54. "Here Comes the Russians Again", Energy Economist, November 1994, 157/18.

55. Petroleum Economist, Mollet, September 1993, p.33.

56. "Oil Shipment From Former Soviet Republics Poses Huge Risks to Turkish Straits", REUTER, Ankara, 10 February 1993.

57. Murat Yetkin, "Turkey Promotes Gas Pipeline From Turkmenistan To Europe", The Turkish Daily News, 9 June 1993, p.3.

58. Pipeline or Pipe-Dream ?", Briefing, 12 April 1993, Issue 934, Ankara, p.7.

59. "Botaş Says Pipeline Projects On the Shelf", ANKA Review, 25 January 1994, p.11.

60. Nazli Ertan, "BOTAS : New Leader, New Priorities", Turkish Probe, 20 January 1994, p.9.

61. "Turkey and Chevron Deepen the Pipeline Blues", Petroleum Economist, July 1993, p.38.

62. Trans-Balkan Parties Sign Protocol for Study of New Pipeline", East European Report, November 1994, EEE 38/19.

63. "New Directions in Energy Finance", Editorial Essay, Petroleum Economist, June 1993.

64. "Energy Sector Responds to DGXVII Energy Policy Paper", EC Energy Monthly, 23 November $1994,71 / 8$.

65. The Turkish Prime Minister, Mrs. Tansu Ciller, during her talks with Russian leaders in Moscow in September 1993, reached agreement on holding a meeting in Ankara of a joint working group of representatives from Russia, Turkey, the US, Kazakhstan and Azerbaijan to discuss the question of laying a transcontinental oil pipeline from Central Asia to Europe. This meeting did not produce any tangible result. See Aldyn Mekhtiyev, "Moscow and Ankara Agree on Many Things", Nezavisimaya Gazeta, 10 September 1993, p.3).The Russian goals may be ai times in conflict with the goals of the Turkish diplomacy; and Turkish moves to act as a regional power may understandably irritate Russia, but it would be wise for both countries, which are bound by 
the geography to coexist, to follow a sound course of mutual understanding. The two countries have common interests in the region (Turkey's trade with Russia is five times greater than with all the Turkic-origin republics combined), not only conflict of interests. The common interests must be pushed to the fore to achieve harmony and co-operation, which would be to the benefit of both countries and the Eurasians. The shipment of Eurasian oil and gas to world markets points to such an area in which a close Turkish-Russian co-operation has become a sine qua non. 66. "Still on the Prowl", The Economist, 28 August 1994, p.13. Russia is now pressing for equity shares in some of the biggest oil and gas projects being undertaken by Western companies in other former Soviet republics, but without putting in any capital. According to a FT news (21 January 1994), LUKOIL is seeking a share of oil and natural gas fields to be developed in Kazakhstan. The move comes only weeks after LUKOIL was allowed to participate in the Azerbaijani government's 30 percent share of a British Petroleum-led consortium to develop offshore Caspian Sea fields. The Russian companies believe they have a valid claim for a share in the big energy developments in neighboring countries because they were discovered during the Soviet era.

67. "A Teddy Bear, After All? Russia and the near abroad", The Economist, 10 December 1994, p.39.

68. Thomas Goltz, "The Hidden Russian Hand : Letter From Eurasia", Foreign Policy, Fall 1993, p.

92.

69. Stephen S. Rosenfeld, "Chechnya Shows the Need for a Long View of Russia" International Herald Tribune, 2 January 1995, p.4.

70. Steve Levine, "South's Oil-Rich Infants Vulnerable to Moscow Bullying", The Financial Times, 20 December 1993.

71. Dimitri K. Simes, "America and the Post-Soviet Republics", Foreign Affairs, p.74.Number 87, Summer 1992. 